\title{
The Protective Role of a Riparian Vegetation to the Sources of a Rural Watershed
}

\author{
Fernando Frachone Neves $^{1^{*}}{ }^{\mathbb{D}}$, Aurélio Teodoro Fontes ${ }^{1}$, André Luiz Oliveira² $^{2}$ \\ ${ }^{1}$ Department of Biology, Faculty of Philosophy, Sciences and Languages of Ribeirão Preto, University of São Paulo, \\ São Paulo, Brazil \\ ${ }^{2}$ Faculty of Technology of Taquaritinga, Taquaritinga, Brazil \\ Email: ^ffneves@terra.com.br, andre.adv@uol.com.br
}

How to cite this paper: Neves, F.F., Fontes, A.T. and Oliveira, A.L. (2019) The Protective Role of a Riparian Vegetation to the Sources of a Rural Watershed. Journal of Water Resource and Protection, 11, 419-433.

https://doi.org/10.4236/jwarp.2019.114025

Received: March 16, 2019

Accepted: April 25, 2019

Published: April 28, 2019

Copyright $\odot 2019$ by author(s) and Scientific Research Publishing Inc. This work is licensed under the Creative Commons Attribution International License (CC BY 4.0).

http://creativecommons.org/licenses/by/4.0/

\begin{abstract}
A recent review of the Brazilian forest law has suggested the possibility of decrease the riparian buffer width along the banks of waterways. This vegetation can trap solutes which had been deposited in the soil and which would otherwise be carried to the waterways in runoff water. In the current study, we applied the AVSWAT model to the Rio Bonito micro-basin of city of Descalvado, State of São Paulo, Brazil, to verify the amount of nitrogen $(\mathrm{N})$ and phosphorous $(\mathrm{P})$ entering the water resource, and to evaluate the environmental protection provided by the riparian vegetation zones. Our results demonstrate this protection is effective in reducing the amount of nitrogen $(\mathrm{N})$ and phosphorous $(\mathrm{P})$ carried to the river. The scenario produced by the data could be used to diagnose the contamination of this particular watershed and to indicate the measures that should be adopted to ensure the restoration and preservation of riparian vegetation zones.
\end{abstract}

\section{Keywords}

AVSWAT, Watershed, Erosion, Nitrogen, Phosphorous

\section{Introduction}

One of the greatest challenges we face in the $21^{\text {st }}$ century is how to conciliate the growing world population and its demand for ever more comfortable lifestyles, with the scarcity of natural resources and the problem of pollution particularly as the growth in world population is followed by increased land occupation and more intense production.

Pollution of water resources due to rural economic activities is especially complex because it is often difficult to identify the source of the pollution. This 
type of pollution is essentially brought about by major hydrologic events and associated not only with the use and occupation of the soil, but also with the pedological characteristics of the particular watershed. Improper land use structure and management will lead to soil erosion and nutrient loss with surface runoff, resulting in a large area of non-point source pollution in the watershed causing loss of nitrogen and phosphorus and water eutrophication [1]. When erosion occurs in agricultural areas, the eroded soil can carry nutrients, but also fertilizers or pesticides [2]. Rainwater carries both organic and inorganic materials that were deposited in the soil and may be soluble in the water sources, significantly increasing its load of pollutants.

Amongst the various chemical elements carried to the waterways, nitrogen $(\mathrm{N})$ and phosphorous $(\mathrm{P})$ can be highlighted as being particularly important, in that they are directly involved in the metabolism of the aquatic life.

In agricultural areas, the riparian vegetation plays an important role in the structure and function of stream ecosystems [3] and can greatly improve the quality of the water of nearby agricultural streams by reducing nutrient leaching in groundwater and surface water runoff, by trapping sediments in surface runoff and thereby decreasing organic or inorganic material loading in surface water even when they comprise little of the total catchment area [4]. The load of nitrate can be effectively reduced by about $30 \%$ by establishing a watershed vegetation buffer [5].

In Brazil, changes have recently been made to the Brazilian federal forest law which sets standards for the protection and use of forests and other forms of vegetation. These changes endanger the water quality of the sources, because they prescribe much less maintenance or reforestation of riparian vegetation than was the case in previous legislation. Prescribing a consistent riparian buffer width has been difficult because there are considerable variations in slope, vegetation composition, soils, etc., determining the level of acceptable risk. Hence, the importance of maintaining critical riparian zone structural and functional attributes relies on the intensity of management activities and the resource(s) needing protection [6]. As a result of inadequate or incomplete knowledge of riparian zone width, farmers are often faced with the challenge of making decisions about appropriate riparian zone protection without a science-based understanding of the structural and functional characteristics that define the riparian area in order to protect stream water quality [7].

In this scenario of uncertainty arising from the recent change in Brazilian federal forest law, the hydrosedimentological model-AVSWAT (ArcView Soil and Water Assessment Tool) has emerged as an important tool for the analysis and evaluation of the environmental protection that riparian zones provide to our watersheds.

We are unaware of any studies that have examined the entry of chemical elements in the sources of the micro basin of Rio Bonito of city of Descalvado, State of São Paulo, Brazil. Thus, this study aims to evaluate the scenario simulated by the AVSWAT model, considering the contribution of nitrogen $(\mathrm{N})$ and phos- 
phorous $(\mathrm{P})$ in response to environmental protection provided by riparian vegetation of this watershed.

\section{Material and Methods}

\subsection{The Hydrosedimentological Model AVSWAT (Arc View Soil and Water Assessment Tool)}

The hydrosedimentological model, AVSWAT, is a mathematical model which was developed in 1996 by the Agricultural Research Service and the Texas A \& M University. AVSWAT is a distributed-parameter model which allows the simulation of several physical processes in watersheds in order to analyze the impact that changes in land use have on runoff and groundwater, sediment yield and water quality in agricultural catchment areas.

The model is capable of simulating long periods of time, divided in days, to compute the effects of different management scenarios, based on a command structure to propagate runoff, sediments and agrochemicals through the basin. The principal components of the model include hydrology, climate, sediment, soil temperature, plant growth, nutrients, pesticides, and agricultural management. The hydrological component of the model includes subroutines for runoff, percolation, lateral subsurface flow, return flow from the shallow aquifer and evapotranspiration. The model requires daily data of e.g. rainfall, maximum and minimum air temperatures, solar radiation and relative humidity. The AVSWAT model uses a modified formulation of the curve number $(\mathrm{CN})$ method to calculate runoff to soil type, land use and management practices [8].

For modeling purposes, AVSWAT subdivides the basin based on its topography, soil type and land use, and thus preserves the spatially distributed parameters of the entire basin, as well as their homogeneous characteristics. The standard process used to divide a basin into sub-basins is to specify boundary areas, which are the minimum areas requiring drainage to a point, forming a channel [9]. Each sub-basin can be parameterized by AVSWAT using a series of Hydrologic Response Units (Hidrologic Response Units-HRU's) which correspond to a unique combination of soils and land within the sub-basin. The HRUs are parts of the sub-basin that have only one combination of land use-soil management. In this way, one or more combinations of land or soil use can be created for each sub-basin. A sensibility level is adopted to eliminate areas of land use smaller than the chosen value.

The AVSWAT model divided the hydrographic micro basin of Rio Bonito of city of Descalvado, State of São Paulo, Brazil, in 41 sub-basins, according to the parameters (HRUs) defined by the model.

\subsection{Monitoring Routine of Nitrogen (N) and Phosphorous (P) Done by the Model}

AVSWAT simulates the complete cycle for the nutrients nitrogen and phosphorous. The model considers the nutrients dissolved in water and those ab- 
sorbed in sediment particles; the former are carried along with the water flow, while the latter are deposited along with sediments at the bottom of the channel. It presents two options: either simulating the nutrients not considering the transformation processes that occur on the river or considering such transformations.

Nitrogen, essential for plant growth, appears in three forms in the soil: organic nitrogen in the humus; mineral forms bound on colloids; and in solution. It can be added to soil by fertilization, fixation by bacteria and rain, and it can be removed by plants, lixiviation, volatilization, denitrification and erosion.

The AVSWAT monitors five forms of nitrogen in soil: two inorganic forms $\left(\mathrm{NH}_{4}^{+}\right.$and $\left.\mathrm{NO}_{3}^{-}\right)$and three organic forms (recent-associated with vegetables and biomass residues, stable and active-associated with humic substances). Figure 1 shows a schematic diagram of the processes in the nitrogen cycle, simulated by the model.

The runoff to the main channel carries organic nitrogen bound to soil particles, which is associated with the sediment load in the HRU. Changes in the sediment load will be reflected directly in the organic nitrogen load. The total of organic nitrogen carried along with sediments to the channel is calculated by the loading function modified by [11]:

$$
\operatorname{orgN}_{\text {surf }}=0.001 \cdot \operatorname{conc}_{\text {orgN }} \cdot \frac{\text { sed }}{\text { area }_{\text {hru }}} \cdot \Sigma_{N: s e d}
$$

where:

$\operatorname{org} N_{\text {surf }}$ is the total of organic nitrogen transported to the main channel by the runoff ( $\mathrm{Kg} \mathrm{N} / \mathrm{ha})$;

conc $_{\text {orgN }}$ is the organic nitrogen concentration in the first $10 \mathrm{~mm}$ of topsoil ( $\mathrm{g}$ $\mathrm{N} /$ ton de solo);

sed is the sediment load on a given day (ton);

area $_{h r u}$ is the HRU area (ha);

$\Sigma_{N}$ is the nitrogen enrichment ratio,

The organic nitrogen concentration in the topsoil, $\operatorname{conc}_{\text {org } N}$, is calculated by the function:

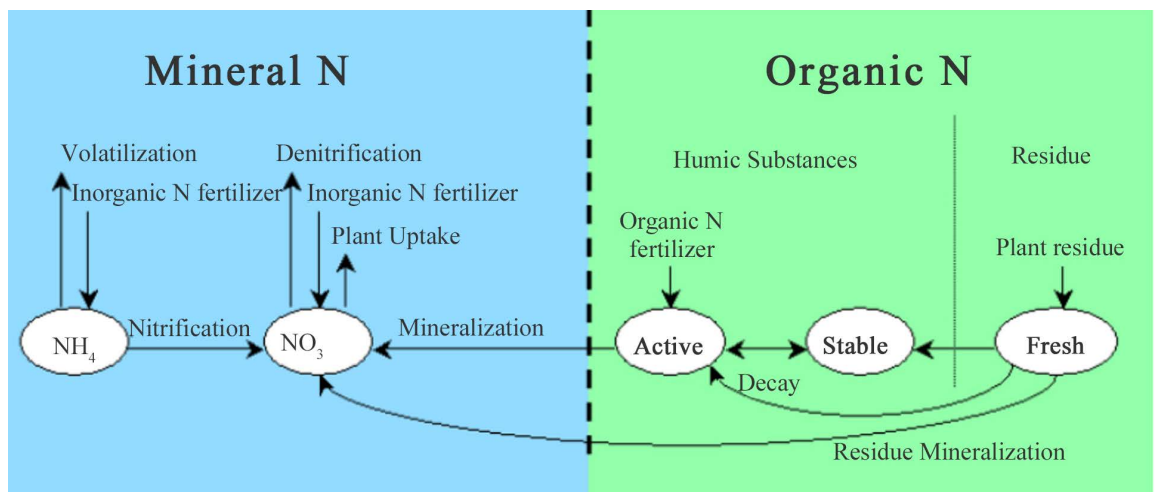

Figure 1. SWAT soil nitrogen pools and process that move nitrogen in and out of pools Source: modified from [10]. 


$$
\operatorname{conc}_{\text {orgN }}=100 \cdot \frac{\left(\operatorname{org} N_{\text {frsh }, \text { surf }}+\operatorname{org} N_{\text {sta, surf }}+\operatorname{org} N_{\text {act }, \text { surf }}\right)}{\rho b \cdot \text { depth }_{\text {surf }}}
$$

where:

$\operatorname{org} N_{\text {frsh,surf }}$ is the nitrogen ( $\mathrm{kg} \mathrm{N} / \mathrm{ha}$ ) in the organic form (fresh) on superficial $10 \mathrm{~mm}$ of soil;

$\operatorname{org} N_{\text {sta,surf }}$ is the organic nitrogen $(\mathrm{kg} \mathrm{N} / \mathrm{ha})$ in the stable form;

$\operatorname{org} N_{\text {act,surf }}$ is the nitrogen $(\mathrm{Kg} \mathrm{N} / \mathrm{ha})$ in the active organic form on superficial $10 \mathrm{~mm}$ of soil;

$\rho_{b}$ is the density $\left(\mathrm{Mg} / \mathrm{m}^{3}\right)$ of soil first layer;

depth $_{\text {surf }}$ is the soil superficial layer deep $(10 \mathrm{~mm})$.

The AVSWAT model simulates the process of mineralization, decomposition, immobilization, nitrification, ammonium volatilization, denitrification, nitrogen due to rain fixation, ascending motion of nitrate in water and lixiviation.

Phosphorous, the other nutrient of interest for this study, is known to be very important for the transfer and storage of energy by plants. There are three forms of the mineral found in soils: organic phosphorous in humus; insoluble forms of mineral phosphorous; and phosphorous in solution which is available to the plants. Phosphorous can be added to the soil by fertilization and removed by both plants and erosion. In combination with other ions, it forms diverse insoluble compounds that precipitate and are easily carried by the runoff.

The AVSWAT monitors six forms of phosphorous in the soil: three inorganic forms (stable, active and in solution) and three organic forms (recent-related to plant residues, stable and active-associated to humic substances). The AVSWAT simulates the processes of mineralization, decomposition, immobilization, absorption of inorganic phosphorous and lixiviation.

Figure 2 shows a schematic diagram of the processes simulated by model in the phosphorous cycle.

As with nitrogen, the organic and mineral forms of phosphorous bound to soil particles are carried by the runoff to the main channel; maintaining the same relation to the sediment load generated by the HRU as described for the nitrogen, i.e., changes in the sediment load will reflect directly in phosphorous load.

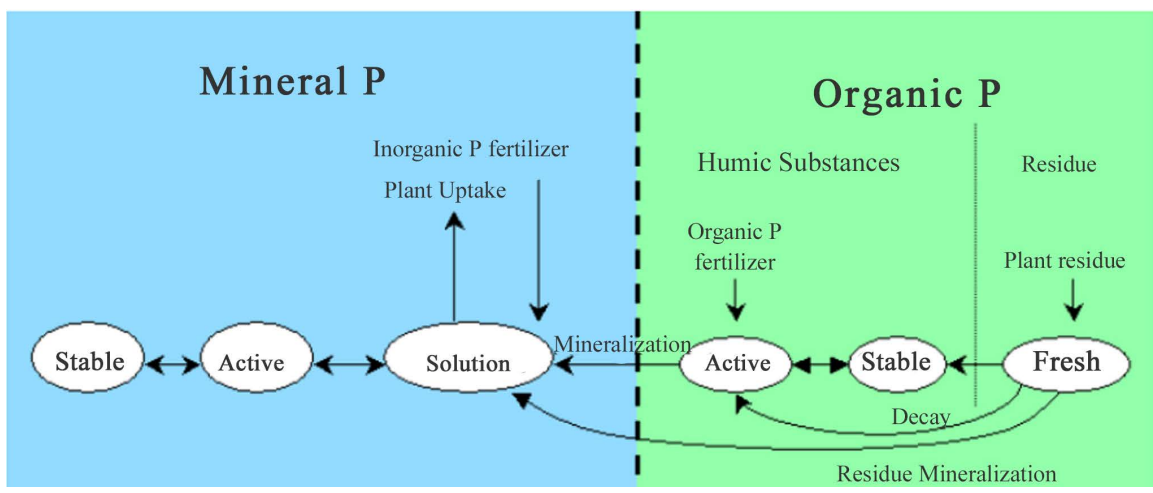

Figure 2. SWAT soil phosphorus pools and processes that move P in and and out of pools. Source: modified from [10]. 
The total of phosphorous carried along with sediments to the channel is calculated by the loading function modified by [11]:

$$
\text { sed }_{\text {surf }}=0.001 \cdot \text { conc }_{\text {sedP }} \cdot \frac{\text { sed }}{\text { area }_{\text {hru }}} \cdot \Sigma_{p: s e d}
$$

where:

sed $P_{\text {surf }}$ is the total of phosphorous (Kg $\mathrm{P} / \mathrm{ha}$ ) carried along with sediments to the main channel by the runoff;

conc $_{\text {sedp }}$ is the concentration of phosphorous ( $\mathrm{g}$ P/ton de solo) bound to sediment in the first $10 \mathrm{~mm}$ of topsoil;

sed is the sediment load (ton) on a given day;

area $_{\text {hru }}$ is the HRU area (ha);

$\Sigma_{P}$ is the phosphorous enrichment ratio.

The phosphorous concentration bound to sediment in the topsoil, conc $_{\text {sedp }}$ is calculated:

$$
\text { conc }_{\text {sedP }}=100 \cdot \frac{\left(\min P_{\text {act, surf }}+\min P_{\text {sta,surf }}+\operatorname{org} P_{\text {hum }, \text { surf }}+\operatorname{org} P_{f r h, \text { surf }}\right)}{\rho b . \operatorname{depth} h_{\text {surf }}}
$$

where:

$\min P_{\text {act,surf }}$ is the total of phosphorous ( $\left.\mathrm{kg} \mathrm{P} / \mathrm{ha}\right)$ in the active mineral form in the first $10 \mathrm{~mm}$ of topsoil;

$\min P_{\text {sta,surf }}$ is the total of phosphorous $(\mathrm{Kg} \mathrm{P} / \mathrm{ha})$ in the stable mineral form in the first $10 \mathrm{~mm}$ of topsoil;

$\operatorname{org} P_{\text {hum,surf }}$ is the total of phosphorous $(\mathrm{kg} \mathrm{P} / \mathrm{ha})$ in the humic organic form in the first $10 \mathrm{~mm}$ of topsoil;

$\operatorname{org} P_{\text {frsh,surf }}$ is the total of phosphorous ( $\mathrm{kg} \mathrm{P} / \mathrm{ha}$ ) in the organic form (fresh) in the first $10 \mathrm{~mm}$ of topsoil;

$\rho_{b}$ is the density $\left(\mathrm{Mg} / \mathrm{m}^{3}\right)$ of the topsoil;

depth $_{\text {surf }}$ is the depth of the topsoil (10mm).

\subsection{Characterization of the Study Area}

The micro basin of Rio Bonito comprehend an area of $223 \mathrm{Km}^{2}$ between the city of Descalvado, State of São Paulo, Brazil $\left(200 \mathrm{Km}^{2}\right)$ and Porto Ferreira, State of São Paulo, Brazil $\left(23 \mathrm{Km}^{2}\right)$, in the central-east region of the State of São Paulo, being delimited by coordinates (in UTM) from 226,200 to 244,000 and from 7558,000 to 7584,000 (Figure 3).

The micro basin is distinguished by its intense poultry industry including areas of high farm concentration, being one of the most important chicken an eggs producers in the Brazil [12] [13]. The farms are concentrated in the following eight sub-basins generated by the model: 4, 10, 20, 22, 24, 28, 30 e 39 (Figure 5), basically following the path of the main channel of the micro basin (Figure 4). This pattern suggests the continued practice of waste and sewage disposal into the aquifers, a fact that seriously damages the quality of water in many areas of agricultural production in Brazil, as shown in the case of the State of Santa Catarina, and more recently, the State of Goiás, [14] [15]. 


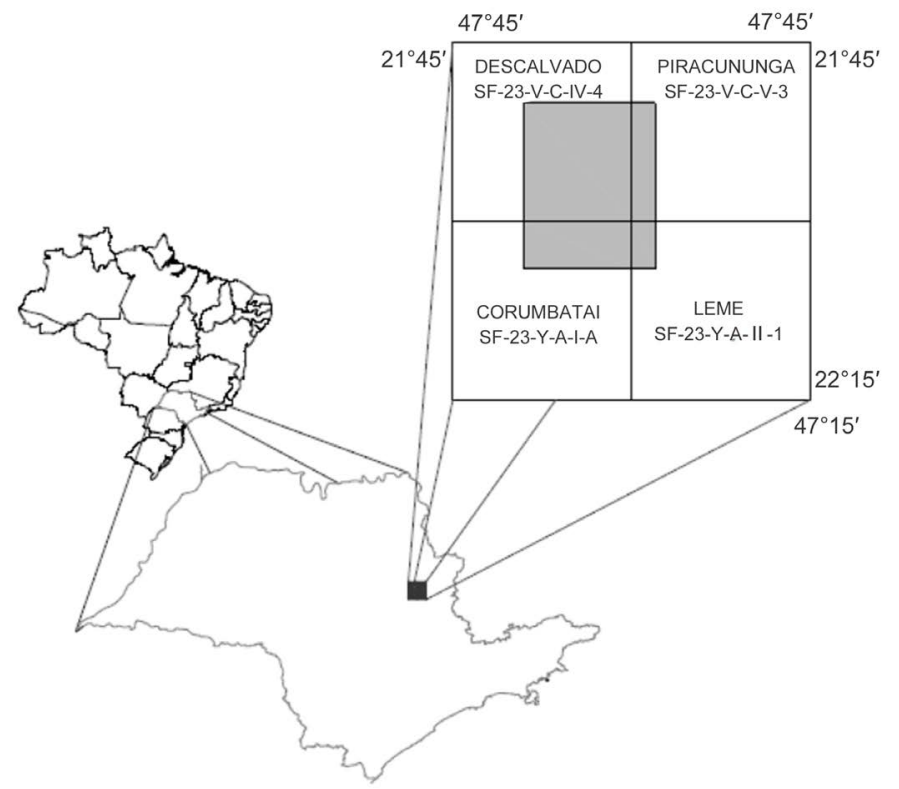

Figure 3. Geographic location of the Hydrographic Micro basin of Rio Bonito. Adapted from Moraes, 2003.

Each one of the forty one sub-basins of the micro basin, numbered as show in Figure 4 and Figure 5, has a different use and activity. However this can be related to economic exploration of soil, there is a predominance of sugar cane, orange orchards, and pastures. The micro basin soil types have a predominance of the Latosoils group, which is predominantly clay as well as others with some significant sand content, which are not the most susceptible regarding erosion (an environmental aspect that is associated with the nutrients' supply in water sources) that may occur due to the use of land already explored, and to the slope of the area, as shown in Figure 6.

This information plan, containing the ranges of slopes was obtained by calculating the continuous values of these slopes through interpolation and data processing of the planialtimetric map, reclassifying them at intervals adapted to the classes of slope limiting agricultural work, allowing a preliminary qualitative evaluation of the susceptibility to erosion, which can result in a silting-up process. It can be seen in the Figure 6 that the south end of the basin is the most susceptible area and that some of the streams are in thalwegs, whose protection demands greater care.

\section{Results}

\subsection{Model Calibration and Statistical Analyzes}

In order to calibrate the AVSWAT model, we considered several sources such as [16] and [17], and also conducted some trial and error tests to identify the variables which appeared to be more sensitive. As a result, the following variables were used to calibrate the model: GW_REVAP, ESCO, EPCO, SOL_AWC, SLSLOPE, SOL_MIN_P, SOL_ORGN and SOL_ORGP, factors C and $\mathrm{K}$ from 

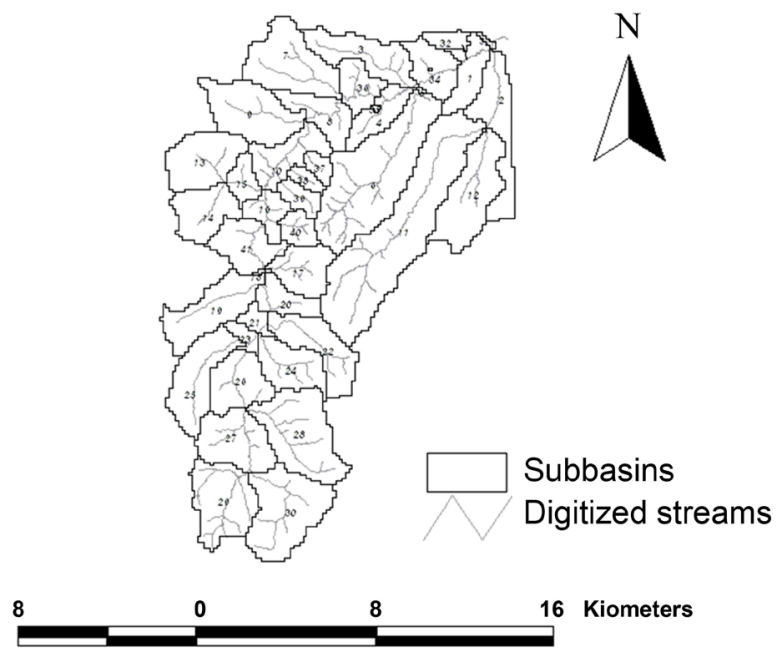

Figure 4. Spatial distribution of the channels in the Hydrographic Micro Basin of Rio Bonito.

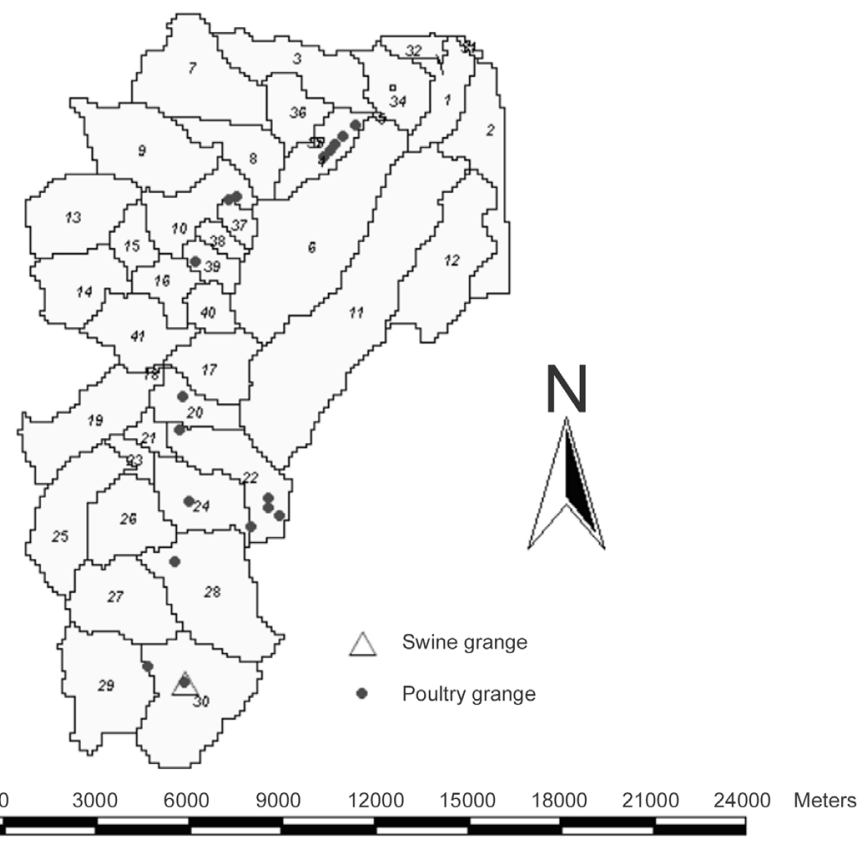

Figure 5. Sub-division of the MBH Rio Bonito in 41 sub-basins and the farms' locations.

Universal Soil Lost Equation, CN, ALPHA_BF, SOL_Z, SOL_NO3, the later four being the most relevant to the study.

[17] suggests several methods to evaluate the calibration of a model and later verify it: the mean absolute error; the determination of coefficient $\mathrm{R}^{2}$ (that indicates what percentage of total variation is explained by linear regression); the Nash-Sutcliffe coefficient and the volumetric difference between the simulated and observed outflows. In the current paper, following [16], we used the Nash-Sutcliffe efficiency coefficients, COE (Equation (5)) in addition to the simulated data deviation related to the observed data, Dv (Equation (6)), which we used to compare some of the parameters obtained in the basin. 


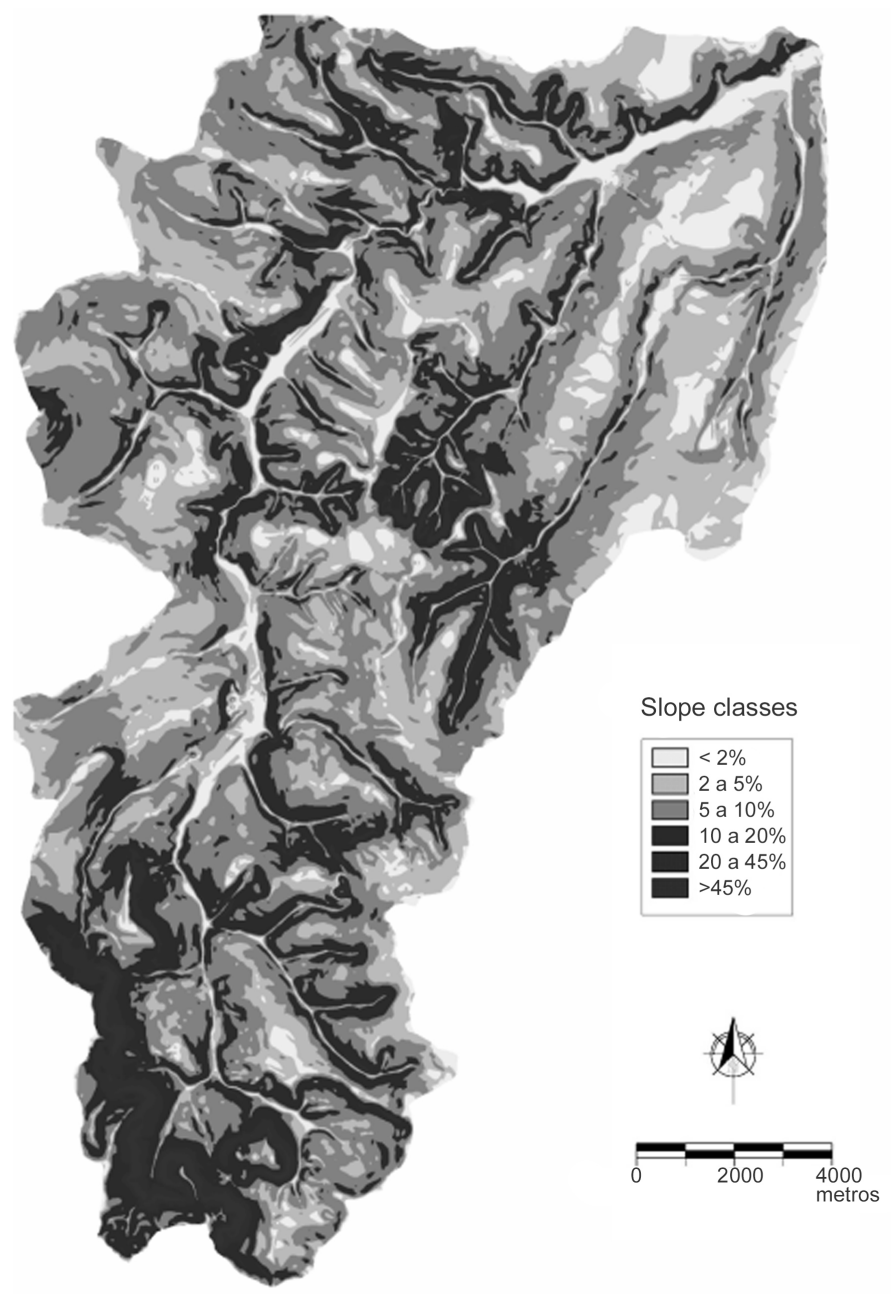

Figure 6. Slope classes of the Hydrographic Micro Basin of Rio Bonito, Descalvado (SP).

$$
\mathrm{COE}=1-\frac{\sum_{i=1}^{n}\left(E_{m}-E_{s}\right)^{2}}{\sum_{i=1}^{n}\left(E_{m}-\bar{E}\right)^{2}}
$$

in which $E_{m}$ is the observed event, $E_{s}$ is the simulated event created by the model; $\bar{E}$ is the mean observed event in the simulation period, and $\mathrm{n}$ is the number of events.

The deviation is presented by Equation (6):

$$
D_{v}[\%]=\frac{E-E^{*}}{E} * 100
$$

in which $E$ is the observed event in the analyzed period, and $E^{*}$ is the simulated event in the period. These two parameters were used to evaluate the model performance.

Results showed that the model had a good estimative potential in relation to the observed data. In general a COE varying from 0.70 to 0.80 indicates a good fit [18]. The COEs for nitrogen and phosphorous were 0.76 and 0.74 , respective- 
ly. The $D_{V}$ (standard deviation) between the observed and simulated values was $-2.8 \%$ for nitrogen and $-2.4 \%$ for phosphorous and these negative values indicates that the simulated amounts of nitrogen and phosphorous production were higher than the observed ones.

\subsection{Nitrogen $(\mathrm{N})$ and Phosphorous $(\mathrm{P})$ Volumes Generated from Animal Dejects}

We used the methodology proposed by [19] to calculate the volumes of nutrients $(\mathrm{N}$ and $\mathrm{P})$ arising from poultry waste in different farms within the micro basin.

The AVSWAT model considers the monthly fertilizer data, meaning that the final values of nitrogen $(\mathrm{N})$ and phosphorous $(\mathrm{P})$, shown in Table 1, were divided by 12 , thus representing the soil fertilization in a homogeneous manner.

The use of this methodology for the nutrients data entry does not influence the model simulation results, since they were parameterized in annual values.

In order to input the fertilizer data, we used each HRU on each sub-basin where there was a farm, i.e., the total volume of animal waste generated in the sub-basins was proportionally distributed over each HRU in this same sub-basin.

To meet the entry unity required by the model (values of fertilizer entry expressed in kilograms per hectare- $\mathrm{Kg} / \mathrm{ha}$ ), the area of their respective HRUs was divided by the total volume of nutrients for each sub-basin; the results are expressed in $\mathrm{Kg} / \mathrm{ha}$.

In decreasing order, the sub-basins presenting higher concentrations of nitrogen $(\mathrm{N})$ and phosphorous $(\mathrm{P})$ in soil were $4,22,20,24$ e 30, 39, 10 and 28, as showed in Figure 7.

\subsection{Simulation of Nitrogen (N) and Phosphorous (P) Entry into the Source}

For the purpose of simulation, we used only the results obtained for the nitrogen $(\mathrm{N})$ and phosphorous $(\mathrm{P})$ nutrients in the organic phase, since animal waste provids them "in natura".

Table 1. Monthly data of fertilizers in the AVSWAT model.

\begin{tabular}{ccc}
\hline & \multicolumn{2}{c}{ KG NUTRIENT/Month } \\
\hline Sub-basin & Phosphorous $(\mathrm{P})$ & Nitrogen $(\mathrm{N})$ \\
\hline 4 & 259.2 & 1500.52 \\
10 & 96 & 555.75 \\
20 & 144 & 833.62 \\
22 & 412.8 & 2389.72 \\
24 & 230.4 & 1333.8 \\
28 & 52.8 & 305.66 \\
30 & 541.5 & 2773.94 \\
39 & 72 & 416.81 \\
Totals & 1808.7 & $10,109.84$ \\
\hline
\end{tabular}




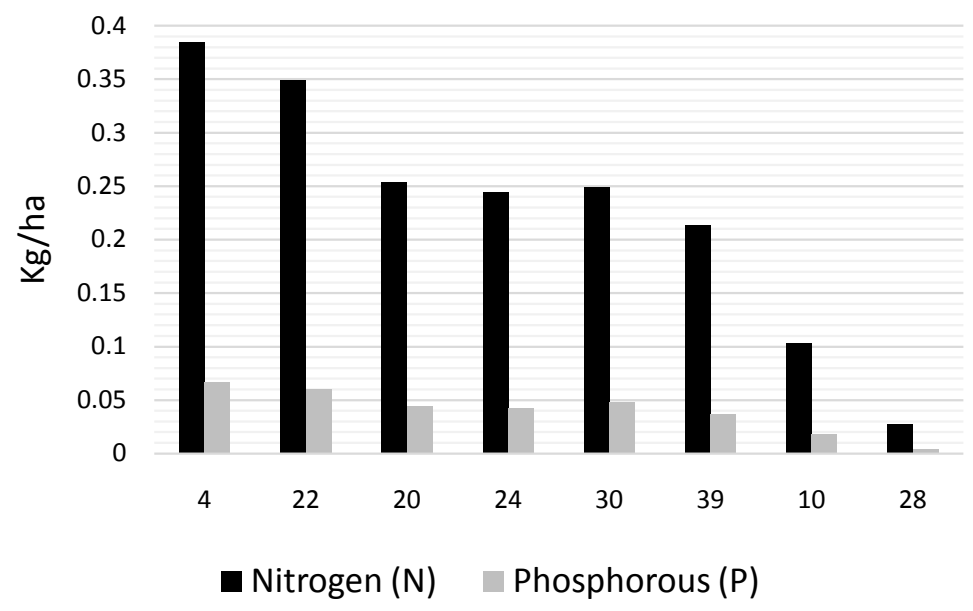

Figure 7. Concentration of nitrogen $(\mathrm{N})$ and phosphorous $(\mathrm{P})$ in each sub-basin including a farm.

In this research, we did not consider mineral forms resulting from the biochemical processes that the organic matter undergoes.

To analyze the effect of fertilization when using animal waste, we simulated the nutrients entries into the sources in two phases. First, we simulated the nutrient's entry without considering the waste entry, so that the model would consider the composition of each soil type and its characteristics nutrients. In the second phase, we went on simulating the nutrient's entry into the channel, considering soil fertilization using animal waste.

In this sense, the Table 2 and Table 3 show the average results (in kilogram of nitrogen $(\mathrm{N})$ and phosphorous $(\mathrm{P})$ entering the micro basin) simulated over a period of 12 years, for which the nitrogen $(\mathrm{N})$ and phosphorous $(\mathrm{P})$ coming from animal waste reached significant values in the sub-basins 4, 20, 10 and 30 .

These results were correlated to the presence of vegetation in the sub-basin, as show in the Figure 8.

\section{Discussion}

The relation between the nutrients carried to the channel and the percentage of the sub-basin covered by vegetation demonstrates the protective function of this vegetation. This indicated that, in some sub-basins, this area was responsible for the retention and accumulation of sediments, and therefore nutrients.

It can be inferred that the runoff slows when it reaches areas of dense vegetation. This is characteristic of the forests, savannas and reforestation areas that comprise the vegetation along the banks of rivers of the area surveyed. Sediments and nutrients carried by the runoff water may thus be retained by vegetation and remain in the sub-basin. This barrier controlled disparate sources of pollution, since it retains solutes, preventing them from spreading across the area [20]. Likewise, the literature indicates the importance of forested areas to the water quality of the sources [21] [22] [23] [24] [25], as well as for the preservation of aquatic biodiversity [26]. 
Table 2. Increment of $(\mathrm{N})$ nitrogen, in $\mathrm{kg} / \mathrm{year}$, entering into the sources of the MBHRB in the period of 12 years of simulation.

\begin{tabular}{cccc}
\hline Sub-basin & $\begin{array}{c}\text { Volume of natural nitrogen } \\
(\mathrm{N}) \text { in the sub-basin } \\
(\mathrm{Kg} / \text { year })^{*}\end{array}$ & $\begin{array}{c}\text { Volume of simulated nitrogen } \\
(\mathrm{N}) \text { considering the entry from } \\
\text { granges }(\mathrm{Kg} / \text { year })^{* *}\end{array}$ & \\
\hline 4 & 107,800 & $158,063.66$ & $50,263.66$ \\
20 & 50,610 & $100,005.23$ & $49,395.23$ \\
10 & 85,430 & $131,659.57$ & $46,229.57$ \\
30 & 4875 & $31,922.05$ & $27,047.05$ \\
28 & 3028 & 6531.42 & 3503.42 \\
22 & 5210 & 7122.17 & 1912.17 \\
39 & 734.6 & 2162.42 & 1427.82 \\
24 & 4049 & 4569.91 & 520.91 \\
\hline
\end{tabular}

Table 3. Increment of $(\mathrm{P})$ phosphorous, in $\mathrm{kg} / \mathrm{year}$, entering into the sources of the MBHRB, in the period of 12 years of simulation.

\begin{tabular}{cccc}
\hline Sub-basin & $\begin{array}{c}\text { Volume of natural } \\
\text { phosphorous }(\mathrm{P}) \text { in the } \\
\text { sub-basin }(\mathrm{Kg} / \text { year })^{*}\end{array}$ & $\begin{array}{c}\text { Volume of simulated phosphorous } \\
(\mathrm{P}) \text { considering the entry from } \\
\text { granges }(\mathrm{Kg} / \text { year })^{* *}\end{array}$ & Increment $(\mathrm{P}) \mathrm{Kg} /$ year \\
\hline 4 & 17,900 & $41,580.06$ & $23,680.06$ \\
20 & 8318 & $31,716.12$ & $23,398.12$ \\
10 & 14,200 & $36,726.55$ & $22,526.55$ \\
30 & 853 & $14,019.93$ & $13,166.93$ \\
28 & 508 & 1652.69 & 1144.69 \\
22 & 8434 & 1900.52 & 1057.12 \\
24 & 6593 & 1165.59 & 506.29 \\
39 & 734,6 & 478.85 & 331.75 \\
\hline
\end{tabular}

${ }^{*}$ Nitrogen $(\mathrm{N}) /$ Phosphorous $(\mathrm{P})$ in soil $(\mathrm{Kg})$ : simulated values considering the carried nutrients naturally present in soil, which come to the sources by superficial flowing. It is not considered the fertilization with animal dejects. ${ }^{*}$ Nitrogen $(\mathrm{N}) /$ Phosphorous $(\mathrm{P})$ total $(\mathrm{Kg})$ : simulated values considering the sum of nutrients naturally present in soil with the nutrients coming from fertilization by animal dejects.
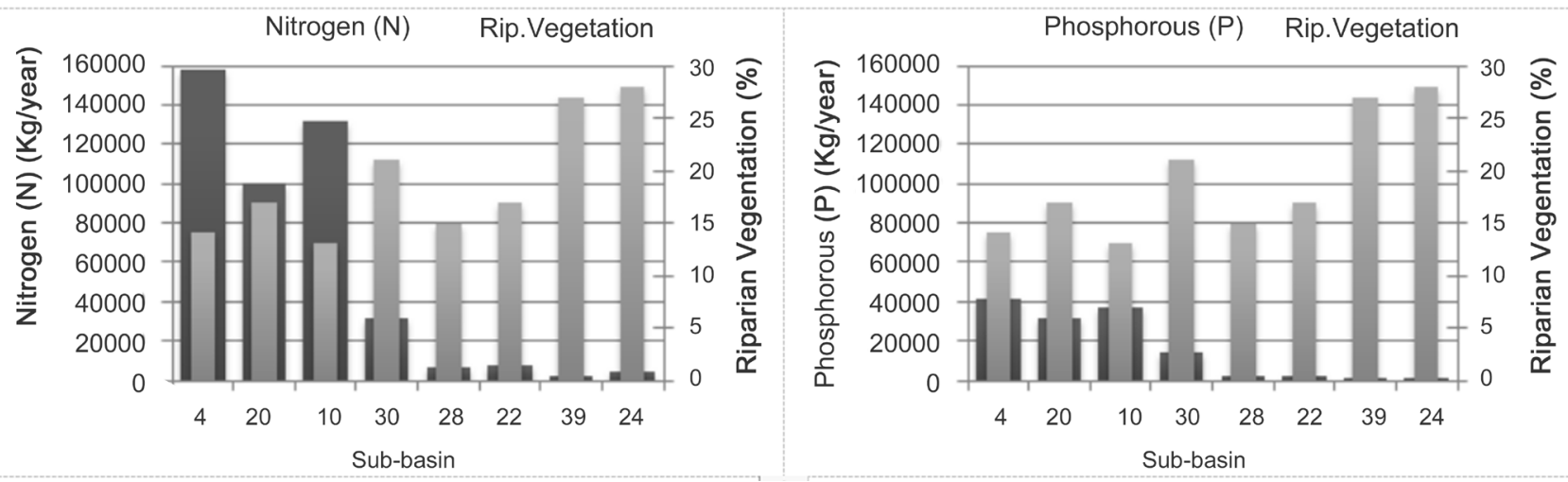

Figure 8. Correlation between the levels of Nitrogen $(\mathrm{N})$ and Phosphorous $(\mathrm{P})$ carried to the channel and the presence of vegetation in the sub-basin. 
It was noted, however, that for sub-basin 30, the vegetation was shown to be ineffective in the control of the supply of nutrients to the sub-basin's channel. This fact is explained by two simultaneous conditions: the first condition, is due to the high concentration of nitrogen $(\mathrm{N})$ and phosphorus $(\mathrm{P})$ released from animal wastes, since it is the only sub-basin that has poultry and pork farms; the second one is the steep slopes found there, as noted in the item relating to the characterization of the study area (the southern end, where the sub-basin is a significant portion of its territory with slopes greater than $20 \%$-ranges " $20 \%$ $45 \% "$ and "> $>5 \%$ ").

One likely reason for the heterogenicity of the protective function of riparian vegetation in all sub-basins is the structure of this barrier, which in some cases is little more than remnants or fragments reducing its effectiveness, besides the possibility of being distributed in areas of steep slopes.

In analyzing the results, the sub-basins $4,20,10$ and 30 require special attention, since they are the most important providers of nitrogen $(\mathrm{N})$ and phosphorous (P) in the watershed. In these areas, one must carefully evaluate fertilization practices, especially the predominant industries of pasture and sugar cane, since other solutes and pollutants could reach the sources of watershed. Likewise, it is recommended that these critical areas should be inspected and monitored in order to confirm that farmers are fulfilling their legal obligation to ensure a barrier of riparian vegetation in the vicinity of sources most directly affected.

Finally, our hope is that our results will help to form the basis of discussion on the protective role of riparian vegetation, a role that has been underestimated by the recent reform of the Brazilian forest law.

\section{Conclusions}

A characteristic on the area surveyed is that the runoff, initiated by the erosion processes, slows when it reaches areas of vegetation along the banks of rivers, retaining the sediments and nutrients that otherwise would be carried by the water to the sources of the sub-basin.

The protective function of riparian vegetation may be compromised by the presence of steep slopes on the ground hence this represents a spatial configuration of the terrain that can increase runoff and nutrient load to the sources.

The existence of areas of riparian vegetation in the watershed has a direct correlation to the nutrient levels carried to the water sources.

This supports the literature on the subject and strengthens the role of this type of vegetation in protecting water resources, generating knowledge to decision makers that define the landscape involving riparian vegetation.

\section{Acknowledgements}

Our acknowledgements go to the Institute of Natural Resources, Federal University of Itajubá, Brazil, and to Dr. Fernando das Graças Braga da Silva, by the 
partnership on this research.

\section{Conflicts of Interest}

The authors declare no conflicts of interest regarding the publication of this paper.

\section{References}

[1] Zhang, P., Liu, Y., Pan, Y. and Yu, Z. (2011) Land Use Pattern Optimization Based on CLUE-S and SWAT Models for Agricultural Non-Point Source Pollution Control. Mathematical and Computer Modelling, 58, 588-595.

https://doi.org/10.1016/j.mcm.2011.10.061

[2] Neves, F.F., Silva, F.G.B. and Crestana, S. (2006) Uso do modelo AVSWAT na avaliação do aporte de nitrogênio $(\mathrm{N})$ e fósforo $(\mathrm{P})$ aos mananciais de uma microbacia hidrográfica contendo atividade avícola. Engenharia Sanitária e Ambiental, 11, 311-317. https://doi.org/10.1590/S1413-41522006000400003

[3] Barling, R.D. and Moore, I.D. (1994) Role of Buffer Strips in Management of Waterway Pollution: A Review. Environmental Management, 18, 543-558. https://doi.org/10.1007/BF02400858

[4] Naiman, R.J., Décamps, H. and McClain, M.E. (2005) Riparia: Ecology, Conservation and Management of Streamside Communities. Elsevier, San Diego. https://doi.org/10.1016/B978-012663315-3/50010-1

[5] Sahu, M. and Gu, R.R. (2009) Modeling the Effects of Riparian Buffer Zone and Contour Strips on Stream Water Quality. Ecological Engineering, 35, 1167-1177. https://doi.org/10.1016/j.ecoleng.2009.03.015

[6] Clinton, B. (2011) Stream Water Responses to Timber Harvest: Riparian Buffer Width Effectiveness. Fuel and Energy Abstracts, 261, 979-988. https://doi.org/10.1016/j.foreco.2010.12.012

[7] Clinton, B.D., Vose, J.M. and Fowler, D.L. (2010) Flat Branch Monitoring Project: Stream Water Temperature and Sediment Responses to Forest Cutting in the Riparian Zone. Res. Pap. SRS-51, U.S. Department of Agriculture Forest Service, Southern Research Station, Asheville.

[8] DI Luzio, M., Srinivasan, R. and Arnold, J. (2001) ArcView Interface for SWAT2000 User's Guide. Blackland Research Center, Texas Agricultural Experiment Station, Temple.

[9] Tribe, A. (1992) Automated Recognition of Valley Lines and Drainage Networks from Digital Elevation Models: A Review and a New Method. Journal of Hydrology, 139, 263-293. https://doi.org/10.1016/0022-1694(92)90206-B

[10] Neitsch, S.L., Arnold, J.G., Kiniry, J.R. and Williams, J.R. (2011) Soil and Water Assessment Tool-Theoretical Documentation. Agricultural Research Service, Temple.

[11] Williams, J.R. and Hann, R.W. (1978) Optimal Operation of Large Agricultural Watersheds with Water Quality Restraints. Texas Water Resources Institute. http://hdl.handle.net/1969.1/6286

[12] Arana, A.R.A. (2002) Os avicultores integrados no Brasil: Estratégias e adaptações o caso Coperguaçu Descalvado SP. Terra Livre-Geografia, movimentos sociais e teoria, 2, 147-162. https://www.agb.org.br/publicacoes/index.php/terralivre/article/view/188

[13] Belusso, D. and Hespanhol, A.N. (2010) A evolução da avicultura industrial 
brasileira e seus efeitos territoriais. Revista Percurso, 2, 25-51.

[14] Gustavo, S.B. and Filho, L.P.G. (2012) Estudo sobre o reaproveitamento dos dejetos de suínos na bacia do Rio Sangão-Santa Catarina. Revista em agronegócio e meio ambiente, 5, 151-174. http://177.129.73.3/index.php/rama/article/view/2201

[15] Santos, A.L.F. and Borges, L.O.S. (2012) Qualidade da água do ribeirão Piancó, GO e suas implicações ambientais. Scientia Plena, 8, 1-7. http://www.scientiaplena.org.br/sp/article/view/766

[16] Machado, R.E. and Vettorazzi, C.A. (2003) Simulação da produção de sedimentos para a microbacia hidrográfica do Ribeirão dos Marins, SP. Revista Brasileira de Ciência do Solo, 27, 735-741. http://www.scielo.br/pdf/rbcs/v34n1/a26v34n1.pdf https://doi.org/10.1590/S0100-06832003000400018

[17] Garrido, R.-J., Damásio, J., Carrera-Fernandez, J. and Silveira, A.H.P. (2003) Impactos da Cobrança pelo Uso da Água: Uma metodologia de avaliação. Revista Bahia \& Análise de Dados, 13, 497-513.

http://www.bvsde.paho.org/bvsacd/cd17/cobravalia.pdf

[18] Krysanova, V., Müller-Wohlfeil, D.-I. and Becker, A. (1998) Development and Test of a Spatially Distributed Hydrological/Water Quality Model for Mesoscale Watersheds. Ecological Modelling, 106, 261-289.

https://doi.org/10.1016/S0304-3800(97)00204-4

[19] Mitchell Junior, C.C. (1991) The Value and Use of Poultry Waste as a Fertilizer. In: Poultry By-Product Management Handbook, Auburn University, Cooperative Extensive Service, Alabama.

[20] Oliveira, L.M. (1998) Controle de fontes dispersas de poluição pela fixação de largura mínima de faixa de vegetação natural ou recomposta ao longo de corpos d'água. Dissertação de Mestrado, EESC/USP, São Carlos.

[21] Fonseca, H.S. (2002) Qualidade das águas superficiais de uma bacia hidrográfica sujeita a processos erosivos-Estudo de caso do Rio Bonito, em Descalvado, SP. Dissertação de Mestrado, UFSCar, São Carlos.

[22] Moraes, M.E.B. (2003) Zoneamento Ambiental de Bacias Hidrográficas: Uma abordagem metodológica aplicada na Bacia do Rio Bonito (SP) Tese de Doutorado. UFSCar, São Carlos.

[23] Ocampo, C.J., Sivapalan, M. and Oldham, C.E. (2006) Hydrological Connectivity of Upland-Riparian Zones in Agricultural Catchments: Implications for Runoff Generation and Nitrate Transport. Journal of Hydrology, 331, 643-658.

https://doi.org/10.1016/j.jhydrol.2006.06.010

[24] Jencso, K.G., McGlynn, B.L., Gooseff, M.N., Wondzell, S.M., Bencala, K.E. and Marshall, A. (2009) Hydrologic Connectivity between Landscapes and Streams: Transferring Reach- and Plot-Scale Understanding to the Catchment Scale. Water Resources Research, 45, W04428. https://doi.org/10.1029/2008WR007225

[25] Jencso, K.G. and McGlynn, B.L. (2011) Hierarchical Controls on Runoff Generation: Topographically Driven Hydrologic Connectivity, Geology, and Vegetation. Water Resources Research, 47, W11527. https://doi.org/10.1029/2011WR010666

[26] Neves, F.F., Avelar, W.E.P. and Lavrador, M.A.S. (2014) Modelling the Risk of Mortality of Corbicula fluminea (Müller, 1774) (Bivalvia: Corbiculidae) Exposed to Different Turbidity Conditions. Brazilian Journal of Biology, 74, 509-514.

https://doi.org/10.1590/1519-6984.21612 